\title{
The Benefits of Colorectal Surgery Surveys in Australia and New Zealand
}

\author{
Auerilius Erastus Ricardo Hamilton ${ }^{1,2}$, Amelia Alice Lin ${ }^{1,2}$, Christopher John Young ${ }^{1,2}$ \\ ${ }^{1}$ Department of Colorectal Surgery, Royal Prince Alfred Hospital, Camperdown, New South Wales; ${ }^{2}$ The University of Sydney, Central Clinical \\ School, Sydney, New South Wales, Australia
}

Purpose: Pertaining to the Colorectal Surgery Society of Australia and New Zealand (CSSANZ) Executive and Research Support Committee, this study aimed to assess the usefulness and outcomes of surveys sent out by the society to its members. Methods: From 2009 to 2017, CSSANZ members received 38 surveys, most of which were distributed from within the society, and a few of which originated from other affiliated groups. Surveys were categorised by type, topics, times required for completion, delivery method, response rates, and advancement to publication.

Results: Of 38 surveys, 20 (53\%) were published and 18 remain unpublished. Four surveys were distributed annually on average, with 2.2 published annually on average, with a mean impact factor of $2.41 \pm 1.55$. Mean time to publication was $31 \pm$ 17 months. Surveys contributed to 13 publications (34\%). The most common survey topics were rectal cancer decisionmaking, in 6 publications (16\%), preoperative assessment of colorectal patients, in 5 publications (13\%), and anal physiology: continence and defaecation, in 4 publications (11\%). Publication of surveys was not related to the number of surveys distributed per year, the number of questions per survey, or the time required by respondents to complete the surveys.

Conclusion: Most of the CSSANZ-distributed surveys resulted in publications, and one third of the surveys contributed to higher degrees obtained by investigators. These surveys aid research into areas that are otherwise difficult to assess, often indicating areas for future research.

Keywords: Survey; Questionnaire; Colorectal surgery; Clinical equipoise

\section{INTRODUCTION}

Some academic surgeons feel that the number of surveys sanctioned by the Colorectal Surgery Society of Australia and New Zealand (CSSANZ) should be culled due to high nuisance effects and limited academic value of the surveys. We aim to present an opposing viewpoint in defence of surveys. Some surgeons within the CSSANZ argue that surveys do not sufficiently meet the research standards mandated for trainees. The Research Support

Received: July 18, 2019 - Accepted: September 17, 2019

Correspondence to: Christopher J. Young, MS FRACS FACS FASCRS

Department of Colorectal Surgery, Royal Prince Alfred Hospital,

Camperdown, New South Wales, Australia

Tel: +61-2-9515-7576, Fax: +61-2-9515-1806

E-mail: cyoungnsw@aol.com

ORCID: https://orcid.org/0000-0002-7213-5137

(C) 2020 The Korean Society of Coloproctology

This is an open-access article distributed under the terms of the Creative Commons Attribution NonCommercial License (https://creativecommons.org/licenses/by-nc/4.0) which permits unrestricted non-

commercial use, distribution, and reproduction in any medium, provided the original work is properly cited.
Committee (RSC) within the CSSANZ oversees all matters pertaining to surveys. The RSC approves 4 to 6 surveys per year, although this number may increase to include surveys not requiring reminders or those sent from affiliate organisations. Researchers often acknowledge their collaboration and cooperation with frequent partners including General Surgeons Australia, New Zealand Association of General Surgeons, the Gastroenterology Society of Australia, and other medical or social coloproctologyfocused groups.

Anecdotally, most CSSANZ surveys have had high response rates (RRs) in comparison to RRs for general surgical surveys, and CSSANZ surveys largely result in publications. Surveys with opaque conclusions due to poor responses struggle to get published unless they are well constructed with interesting topics. Four or more researchers often draft surveys in collaboration before submission to CSSANZ for consideration. The logistical processes of submitting and completing surveys are achievable, consistent, and clearly known. Submissions undergo rigorous screening and scrutiny by RSC officers, often with 9 to 13 passes in the 
drafting process, before progressing to general committee review. Successfully screened surveys that are circulated traditionally return quick, helpful, and much-appreciated responses by assiduous members. In recent years, RSC officers have anecdotally noticed a reduction in $\mathrm{RR}$ in cycles wherein higher numbers of surveys are distributed, or in cases where surveys are spearheaded by nonmembers (regardless of investigators' level of training). Surveys tend to be more successful if they are sponsored by CSSANZ members (especially for non-member applications), if they are well constructed, if they avoid repetitive topics, and in correspondence to online versus paper copies. Between the 2 countries of Australia and New Zealand, surveys distributed by post present great challenges, which are slightly mitigated when researchers use prestamped, self-addressed return envelopes. Some responding surgeons have kindly scanned paper surveys and returned them by email.

Following completion of their research, investigators face the arduous task of securing publication in reputable journals. Anecdotally, journal houses in our region disfavour publishing surveyrelated research, preferring instead to change survey-based articles to Perspective papers of 800-1,000 words. Researchers are then driven to publish externally in other international journals with higher impact factors with larger readership numbers. Hence, opportunities are lost to locally showcase homegrown research.

Surveys struggle to gain acceptance in the discourse on general surgery, and not surprisingly, the same hurdles are faced in colorectal surgery. Surveys face the challenge of overcoming many biases both intrinsic and extrinsic. Intrinsic biases in cross-sectional studies can include selection bias, nonresponse bias, information biases such as recall bias and detection bias, and confounding bias. Extrinsic biases can come from individual readers, editorial organisations, journal houses, and speciality group prejudices. We hope that the present study reduces some of the extrinsic biases toward colorectal surveys in Australia and New Zealand.

\section{METHODS}

This study aims to assess the outcomes and benefits of CSSANZdistributed surveys over a 9-year period. It addresses several questions, as follows. (1) In typical surveys, what topics are being investigated and which question types are being asked? (2) What rate of CSSANZ surveys formally progresses to positive literary outcomes in publications and/or dissertations for higher degrees? (3) How does the publication rate for these CSSANZ surveys compare to the publication rate for submitted Royal Australasian College of Surgeons research abstracts?

Between 1st January 2009 and 31st December 2017, the CSSANZ distributed 38 surveys to its members. Subsequently, all of the surveys were retrospectively analysed as of census date 30th June 2018. The majority of these surveys (92\%) were spearheaded by CSSANZ members. A few surveys (8\%) were looked after by other affiliate groups - namely, the Lowry Cancer Research group of the University of New South Wales, Crohn's and Colitis Australia, and the Gastroenterology and Liver Services at Concord Hospital NSW of the University of Sydney. Each survey had its own initial ethics approval, and later, the CSSANZ Executive Committee approved a comparative "survey of these surveys." We reviewed all questionnaires held by the Secretariat and manually counted the number of questions for each. All publications were found via PubMed, MEDLINE, and/or Google Scholar. For our purposes of analysis herein, survey types are categorised into discrete categories of referral pathways, current practices, decisionmaking, or knowledge and skills assessment. For consensus, our authors independently categorised each survey based on their title wording, questionnaire structure, or conclusions from subsequent publications. Where initial consensus was not met on categorisation, agreement was later finalised by panel discussion. Survey topics are categorised into one of the listed chapters from the Table of Contents from the American Society of Colon and Rectal Surgeons Textbook of Colon and Rectal Surgery [1]. Survey times refer to the estimated minutes required for participants to complete a survey as stated by investigators. Time to publication in months measures the time from survey submission to the Secretariat for distribution to the acceptance date for publication according to the article title page or the electronic-publication date in the citation.

The survey delivery method is listed as either "paper" (for telephone or postal mail) or "electronic" (online platforms or emailed questionnaires) depending on response collection as opposed to questionnaire-distribution. Those with online questionnaires used platforms including KeySurvey (Braintree, MA, USA); SurveyMonkey (SurveyMonkey, San Mateo, CA, USA); Google Docs (Google, Mountain View, CA, USA); or Vista (Vanguard Software Corp., Cary, NC, USA). Links to questionnaires were sent by email or by advertisements in relevant societies' newsletters or journals. Commonly, after a questionnaire was dispersed, 1 or (on rare occasion) 2 reminders were issued as follow-up at intervals of 2 weeks apart. After the passage of 2 months, many investigators ceased to accept survey responses.

RRs from CSSANZ members were calculated with respondent numbers reported by investigators functioning as the numerator and questionnaire-distribution numbers reported by the Secretariat functioning as the denominator. RRs from non-members were chart listed, but not included in our analysis. An RR was "not defined" for surveys generically sent to non-CSSANZ members of large organisations where only the numerator of respondent numbers was known. Due to missing data from unpublished surveys for some of the defined elements above, complete analysis of RR for all 38 surveys was not possible.

The authors individually scored all surveys with the newly developed yet unvalidated qualitative Young's Survey Score (YSS), shown in Fig. 1, as developed by this paper's senior author (CJY). 


\begin{tabular}{|c|c|c|}
\hline Item Number & Question item & Score (0 to 50$)$ \\
\hline 1 & $\begin{array}{l}\text { Is it an interesting topic for most } \\
\text { members? }\end{array}$ & 0 to 10 \\
\hline \| & $\begin{array}{l}\text { Is it an important topic that } \\
\text { members would benefit from the } \\
\text { answers? }\end{array}$ & 0 to 10 \\
\hline III & $\begin{array}{l}\text { Has thia topic been surveyed } \\
\text { recently in the last } 2 \text { years? }\end{array}$ & $\begin{array}{l}\text { Yes }=0 \\
\text { Partly }=5 \\
\text { No }=10\end{array}$ \\
\hline IV & $\begin{array}{l}\text { How long does it take } \\
\text { respondents to complete? } \\
16 \text { to } 30 \text { minutes }=0 \text { to } 5 \\
11 \text { to } 15 \text { minutes }=6 \text { to } 7 \\
5 \text { to } 10 \text { minutes }=8 \text { to } 10\end{array}$ & 0 to 10 \\
\hline V & $\begin{array}{l}\text { How easy is it to answer the } \\
\text { questions and return the } \\
\text { answers, by whatever means, } \\
\text { electronic or paper? }\end{array}$ & $\begin{array}{l}\text { Online }=10 \\
\begin{array}{l}\text { Paper and self-addressed } \\
\text { envelope }=5\end{array}\end{array}$ \\
\hline
\end{tabular}

Fig. 1. Young's Survey Score developed by the senior author.

The YSS gives a rating according to 5 questions asked of each survey, with scores marked out of 10 for a maximum total of 50 points. The scores examined for each survey include dimensions of the topic's interest and importance to CSSANZ membership, currency of similar topics in circulation, length of time required for respondents to complete surveys, and ease of answering based on delivery method. The summative score intends to quantify these 5 variables as a novel quality scoring system for surveys in colorectal surgery. For consensus, an average was taken of individual authors' scores for each survey.

RRs from unpublished surveys were unknown by the Secretariat or were not obtainable from the primary investigators at the time of this study. Based on published surveys, we listed the topics of each survey according to their topic subject matter, and divided them into high RR $(\geq 50 \%)$ or low RR ( $<49 \%)$ by CSSANZ members. As of the study census date, we did not have full details regarding the fate of unpublished surveys. Two surveys are confirmed to have ceased-1 due to poor responses and 1 that did not progress. The other surveys are currently facing the ongoing challenge of finding a suitable journal organisation for publication.

\section{RESULTS}

Over the 9-year study period, the CSSANZ annually distributed a mean \pm standard deviation (SD) of $4 \pm 2$ surveys with a mean annual publication rate of 2.2 (55\%), as shown in Fig. 2. Regarding the 38 surveys overall, the 3 most common survey topics, as shown in Supplementary Table 1, were rectal cancer decision-making, in 7 publications (16\%), preoperative assessment of colorectal patients, in 6 publications (13\%), and anal physiology: continence and defaecation, in 5 publications (11\%). The collective outcomes of the surveys' delivery methods, number of questions, number of pages, survey quality, distribution per year, and survey type frequency of use are shown in Table 1.

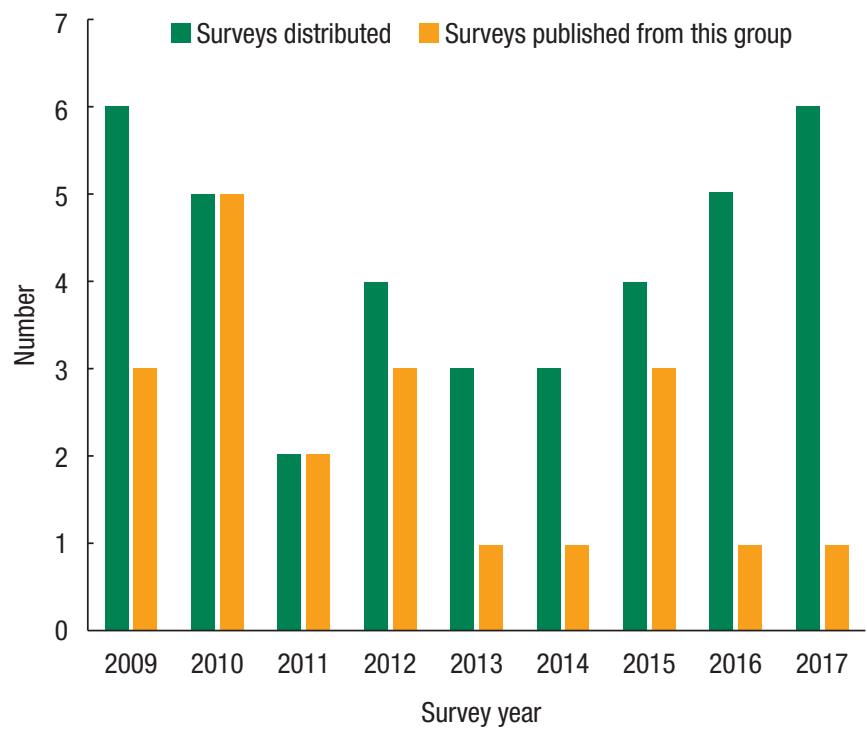

Fig. 2. Number of surveys distributed and subsequently published each year by CSSANZ from 2009 to 2017. CSSANZ, Colorectal Surgery Society Australia and New Zealand.

Regarding positive literary outcomes, 20 surveys (53\%) were published as of census date 30th June 2018. The survey results are shown to have contributed to 13 higher degrees, comprising 3 $\mathrm{PhDs}$ and 10 Masters degrees, as shown in Supplementary Table 2. Fig. 3A [2-21] and Supplementary Table 3, respectively, show a summarised and expanded list of these surveys and their RRs. For published surveys, the mean \pm SD of RR from CSSANZ members was $53 \% \pm 18.3 \%$, as depicted in Fig. $3 \mathrm{~B}$, and the mean \pm SD impact factor was $2.41 \pm 1.55$ for publishing journals, as shown in Fig. 4A [22-24]. Fig. $4 \mathrm{~B}$ shows a mean $\pm \mathrm{SD}$ time to publication for relevant surveys of $31 \pm 17$ months. Fig. 5 shows a KaplanMeier analysis with "publication" being the event of interest. Surveys with a YSS of $\geq 37 / 50$ were more likely to be accepted for publication $(\mathrm{P}=0.027)$, with a mean publication time of 36.5 months for this subgroup.

For the 38 surveys, comparison analyses of the methods of delivery and progression to publication are shown in Tables 2 and 3 . The progression of surveys to publication was not influenced by the number of survey questions, number of pages, time required to complete the survey, or the number of surveys distributed in a year. Investigators undertaking a higher degree were more likely $(\mathrm{P}<0.001)$ to use paper-based surveys. The factors used for univariate and multivariate analysis were surveys' methods of delivery, YSSs, and occurrence in the first or second half of the study period to remove lead-time biases, as shown in Table 4. From these analyses, surveys with a YSS of $\geq 37 / 50$ were significantly more likely to be accepted for publication. Table 5 shows topics from 20 published surveys and their categorised RR with no obvious correlation between the topic subject matter and the incidence of high or low RRs. 
Table 1. Demographics and survey types of CSSANZ surveys, 2009$2017(\mathrm{n}=38)$

\begin{tabular}{|c|c|}
\hline Variable & Value \\
\hline \multicolumn{2}{|l|}{ Published } \\
\hline Yes & $20(53)$ \\
\hline No & $18(47)$ \\
\hline \multicolumn{2}{|l|}{ Higher degree } \\
\hline Yes & $13(34)$ \\
\hline No & $25(66)$ \\
\hline \multicolumn{2}{|l|}{ Method of delivery } \\
\hline Electronic & $23(60)$ \\
\hline Paper & $15(40)$ \\
\hline No. of questions per survey & $37 \pm 24(7-20)$ \\
\hline \multicolumn{2}{|c|}{ No. of pages of questionnaire (median $=5$ ) } \\
\hline$\leq 5$ Pages & $27(73)^{\mathrm{a}}$ \\
\hline$\geq 6$ Pages & $10(27)^{a}$ \\
\hline \multicolumn{2}{|c|}{ No. of questions per survey (median = 28) } \\
\hline$\leq 28$ Questions & $19(51)^{\mathrm{a}}$ \\
\hline$\geq 29$ Questions & $18(49)^{\mathrm{a}}$ \\
\hline Survey quality (YSS) & $37 \pm 5(24-46)$ \\
\hline \multicolumn{2}{|l|}{ Distribution amount per year } \\
\hline 2-4 Surveys/yr & $16(42)$ \\
\hline 5-6 Surveys/yr & $22(58)$ \\
\hline \multicolumn{2}{|l|}{ Survey types frequency of use } \\
\hline Referral pathways & $1(3)$ \\
\hline Current practices & $33(87)$ \\
\hline Decision-making & $17(45)$ \\
\hline Knowledge and skills assessment & $16(42)$ \\
\hline \multicolumn{2}{|l|}{ Published surveys $(n=20)$} \\
\hline Response rate & $52.5 \pm 18.3(7.3-75.3)$ \\
\hline Time to publication (mo) & $31 \pm 17(5-59)$ \\
\hline IF of publishing journals & $2.41 \pm 1.55(0.03-7.20)$ \\
\hline
\end{tabular}

Values are presented as number (\%) or mean \pm standard deviation (range). CSSANZ, Colorectal Surgery Society of Australia and New Zealand; IF, impact factor; YSS, Young's Survey Score.

aData missing from one survey.

\section{DISCUSSION}

This study showed that CSSANZ-distributed surveys had a high RR from members, with the majority resulting in publication and with one third of completed surveys contributing to investigators' advancement to higher degrees. Investigators doing higher degrees more commonly $(\mathrm{P}<0.001)$ used paper-based questionnaires, probably due to the clerical structure, research support resources, and preference of common research offices wherein many of them matriculated. There was no significant influence on the progression of surveys to publication due to the number of surveys distributed each year, the number of questions, number of pages, method of delivery, or the time required for participants to complete the surveys. This refutes previously held beliefs about disincentives in potential respondents' desire to participate in surveys among CSSANZ members. There were combinations of surveys types used with the following frequencies: referral pathways, in 1 survey (3\%), current practice, in 33 surveys (87\%), decisionmaking, in 17 surveys (45\%), and knowledge and skills assessment, in 16 surveys (42\%). Through analysis herein, surveys are shown to aid research into areas that are otherwise hard to assess. Moreover, surveys often indicate areas for future research. For example, a questionnaire on diverticulitis circulated by Siddiqui et al. [20] revealed a lack of consensus, and highlights practices that disagree with current treatment guidelines. This meaningful discrepancy certainly needs further explanation via future research. These findings are not discernible from randomized controlled trial (RCTs), which cannot predict opinions. Areas of investigation and question types that are typically addressed in surveys cannot be answered by RCTs. Importantly, surveys tend to lead to or unearth areas where RCTs may be needed for more robust understanding of current topics.

In comparison to regional trends for all research types from all surgical disciplines, CSSANZ surveys are shown to have a high mean publication rate $(53 \%)$, but a long mean \pm SD publication time of $31 \pm 17$ months. The investigative work of Khajehnoori et al. [25] shows that $26 \%$ of abstracts submitted to the Annual Scientific Congress of the Royal Australasian College of Surgeons were subsequently published, with $74 \%$ of these accepted $\leq 24$ months from original submission of the abstract.

Of the 38 surveys, 6 surveys (16\%) were published in regional journals. Despite reviewing 117 self-administered surveys from 34 high impact factor international journals over 1 year, Bennett et al. [26] found that most journals provided no guidance to authors for reporting survey research. The work asserts that surveybased research needs to be reported transparently so readers and reviewers can critically assess the strengths and weaknesses of the design, methodology, and analysis therein. Currently, there is no quality scoring system for surveys in colorectal surgery. Thus, we propose our YSS for internal assessment of CSSANZ-distributed surveys. In the future, we hope to analyse whether there are correlations between YSSs, rates of responses, and publication.

The work of Edwards et al. [27] gives practical tips for improving survey-based RR data collection in postal and electronic questionnaires, although our study shows that neither method influences progression to publication. The work of Hing et al. [28] suggests that questionnaire RR can be improved by optimising study design and including incentives. Despite assessing survey design, our study is not able to analyse the influence of incentives due to missing information from our cohort. According to Alderman and colleagues, the medical research field uses 3 main types 
Summary of published surveys $(n=20)$

\begin{tabular}{|lcc|}
\hline \multicolumn{1}{|c|}{ Author (publication year) } & $\begin{array}{c}\text { Overall } \\
\text { respondents } \\
\text { (total surveys } \\
\text { sent) }\end{array}$ & $\begin{array}{c}\text { CSSANZ } \\
\text { Respondents } \\
\text { (surveys sent) }\end{array}$ \\
\hline Spigelman AD et al [2] (2013) & $33(49)$ & $12(66)$ \\
Jorgensen ML et al [3] (2011) & $102(146)$ & $102(146)$ \\
MacDermid E. et al [4] (2014) & $110(146)$ & $110(146)$ \\
Kahokehr A et al [5] (2011) & $82(152)$ & $82(152)$ \\
Leong RW et al [6] (2015) & $264(539)$ & $46(128)$ \\
Ooi K et al [7] (2012) & $108(174)$ & $108(174)$ \\
Suen MK et al [8] (2015) & $96(148)$ & $96(148)$ \\
Warrier SK et al [9] (2013) & $114(189)$ & $114(189)$ \\
Behrenbruch Cet al [10] (2015) & $66(154)$ & $66(154)$ \\
Hong JS et al [11] (2014) & $107(152)$ & $107(152)$ \\
Smart P et al [12] (2013) & $128(204)$ & $128(204)$ \\
Holt DQ et al [13] (2017) & $1064($ ND) & $12(165)$ \\
Al-Mozany N. et al [14] (2017) & $113(165)$ & $113(165)$ \\
Ansari N. et al [15] (2015) & $106(165)$ & $106(165)$ \\
Burnett D. et al [16] (2018) & $216(782)$ & $111(190)$ \\
Jaung R et al [17] (2016) & $118(236)$ & $99(200)$ \\
Chen Yet al [18] (2017) & $181($ ND) & $73(160)$ \\
Zahid A. \& Young CJ [19] (2017) & $126(202)$ & $126(202)$ \\
Siddiqui J. et al [20] (2017) & $102(205)$ & $102(205)$ \\
Chittleborough et al [21] (2018) & $72(2100)$ & $52(188)$ \\
\hline CSSANZ, Colorectal Surgical Society of Australia \& New Zealand; \\
RR, Response rate; ND, Not defined.
\end{tabular}

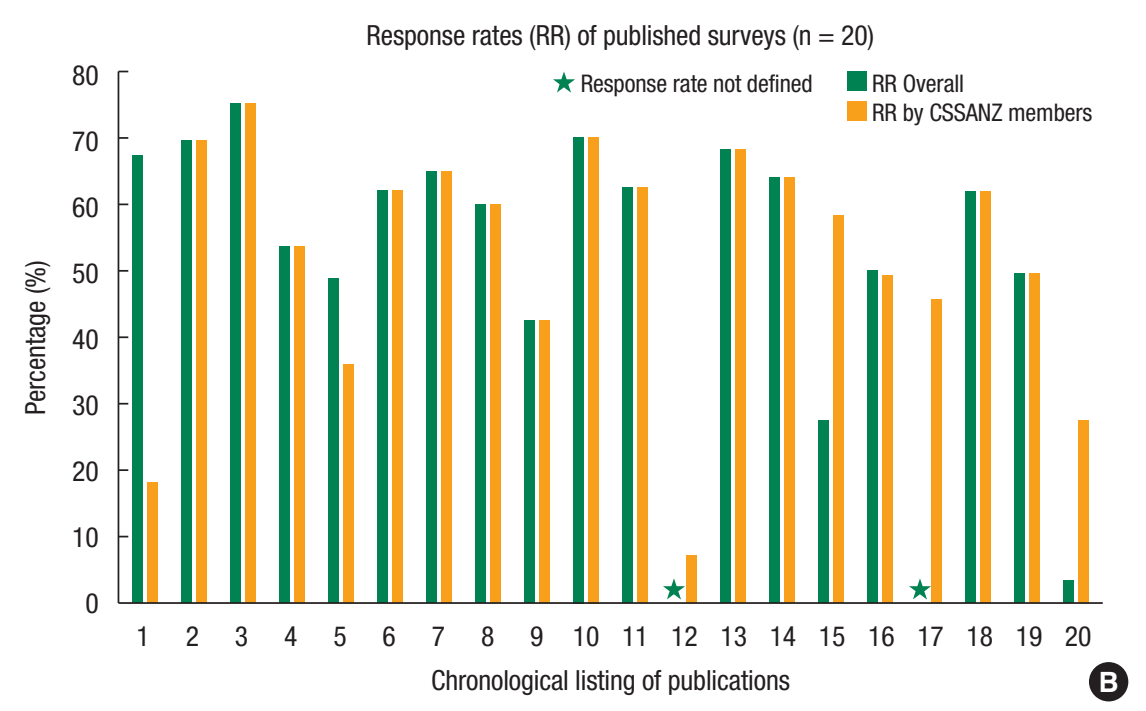

Fig. 3. Summary of CSSANZ surveys 2009-2017 subsequently published. (A) Number of individual surveys sent to candidates and received from respondents. (B) Response rates to each survey project from all respondents and from CSSANZ members. CSSANZ, Colorectal Surgery Society Australia and New Zealand.
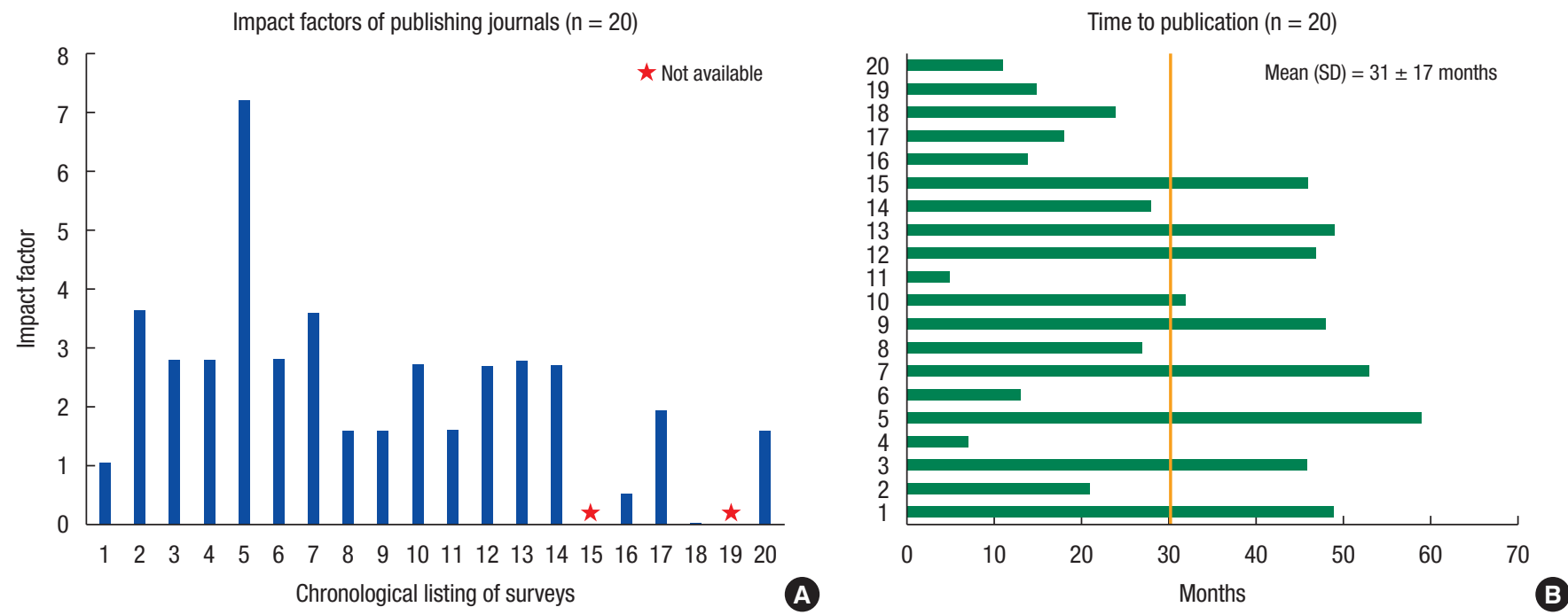

Fig. 4. Summary of CSSANZ surveys 2009-2017 subsequently published. (A) Impact factor of journal of publication for each survey project. (B) Time to publication for each survey project. CSSANZ, Colorectal Surgery Society Australia and New Zealand.

of surveys: (1) epidemiological surveys, (2) surveys on attitudes toward a health service or intervention, and (3) questionnaires assessing knowledge on an issue or topic [29]. In CSSANZ-distributed surveys, our categorisation was into 4 survey types, closely paralleling the above.

We advise future survey investigators to consider the following:
- Dutifully report to the Secretariat all positive literary outcomes including public showcasing at scientific meetings (oral presentations, posters, and/or abstracts), or at workshops (oral presentations).

- Analyse how your survey influences policy changes in your organisation at various levels (surgical units, department-wide, 


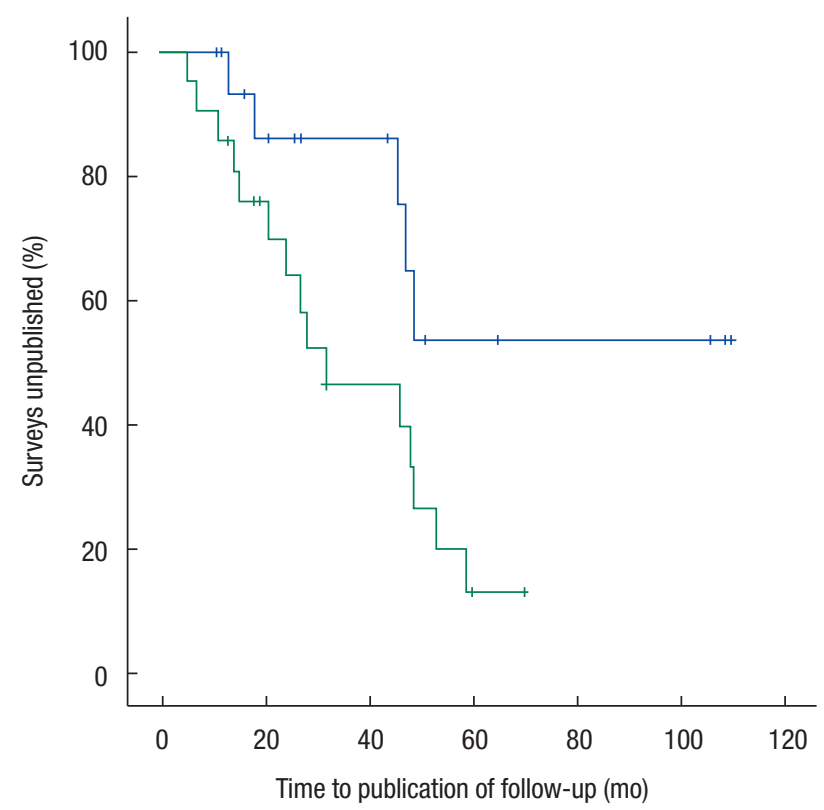

\begin{tabular}{l|c|c|c|c}
\hline Survey score group & $\begin{array}{c}\text { No. } \\
\text { events }\end{array}$ & $\begin{array}{c}\text { Mean months (SE), } \\
95 \% \mathrm{Cl}\end{array}$ & $\begin{array}{c}\text { KM } \\
\text { P-value }\end{array}$ & $\begin{array}{c}\text { Adjusted P value } \\
\text { (HR [CI]) }\end{array}$ \\
\hline$\geq 37 / 50$ & $15 / 21$ & $36.5(4.8), 27.1-45.9$ & \multirow{2}{*}{0.027} & \multirow{2}{*}{$0.028(2.95[1.1-8.1])$} \\
\hline$<37 / 50$ & $5 / 17$ & $76.7(11.3), 54.6-98.8$ & & \\
\hline
\end{tabular}

Fig. 5. Time to publication by Survey Score groups for CSSANZ surveys 2009-2017 subsequently published. CSSANZ, Colorectal Surgery Society Australia and New Zealand; SE, standard error; CI, confidence interval; KM, Kaplan-Meier; HR, hazard ratio.

hospital-wide, and/or area/regional health districts).

- Utilise smartphone technologies with applications linked to secure online survey platforms for more efficient and rapid questionnaire delivery, reminder distribution, and response collection. Numerous commercial applications currently exist, and in the future, applications may be custom-developed for the CSSANZ.

- Consider sending up to 4 reminders fortnightly, ideally electronically, as one reminder seems politely insufficient.

Following this study, we will advocate for an increase from 4-6 surveys to 7-8 surveys per year, with similar expectations for positive literary outcomes, as proven herein. Changes in journal submission policies, along with consistent and clear reporting guidelines for colorectal surgery survey research, may help retain publication of future surveys in Australasia. Surveys indicate areas of equipoise where further research may be useful. We advocate for greater discussion within the CSSANZ to use each sanctioned survey as an impetus for greater policy discussion, for more frequent scrutiny of guidelines, and for further research by its membership.

Future investigators are encouraged to clearly state the immediate aims and long-term goals of their surveys. When CSSANZ
Table 2. Comparison of CSSANZ surveys 2009-2017 by method of delivery $(\mathrm{n}=38)$

\begin{tabular}{lccc}
\hline Variable & Electronic & Paper & P-value \\
\hline Published & & & \\
Yes & $11(29)$ & $9(24)$ & $0.34^{\mathrm{a}}$ \\
No & $12(32)$ & $6(16)$ & \\
Impact factor of journal & $2.50 \pm 1.86$ & $2.30 \pm 1.16$ & $0.78^{\mathrm{b}}$ \\
& $(0.48-7.20)$ & $(0.03-3.57)$ & \\
Higher degree associated & & & \\
Yes & $2(5)$ & $11(29)$ & $<0.001^{\mathrm{a}}$ \\
No & $21(55)$ & $4(11)$ & \\
\hline
\end{tabular}

Values are presented as number (\%) or mean \pm standard deviation (range). CSSANZ, Colorectal Surgical Society of Australia and New Zealand. ${ }^{a}$ Fisher exact test. ${ }^{b}$-test.

surveys appear to forecast trends, deviations from guidelines, or insights beyond the scope of opinion polls or practice audits, this shift may lead to increased survey acceptance by colorectal surgeons and to better survey assessment of benefits in clinical practice. All past investigators fully appreciate the support of CSSANZ membership in assisting in projects that stand to help all practitioners in colorectal surgery understand areas for further research. The invaluable amount of time spent, contributions made, and the innate culture of research camaraderie among members facilitates cooperative participation and commendable RRs to these important surveys.

This was a retrospective review with all the intrinsic limitations of nonrandomisation. In addition, our review is limited by the nonresponse bias, which is a weakness of all surveys. As highlighted in this study, the impact factor only represents a score for the popularity of journal readership, and not for research quality. Missing information about respondents' locations, duration of time spent to collect data, distribution of reminders, and RRs from unpublished surveys prevent a more in-depth analysis of non-RRs.

The present study does not explore the multifactorial factors that influence RRs (negatively or positively). Our data collection was significantly incomplete, and hence, contrary to the plan of study, no analysis was made in areas including time taken by investigators to collect data, number of reminders sent, method of reminder, timing of reminder, recruitment incentives used, geographical location (country, state, and city) of surveyed participants, and age of participants. The small sample size may have accounted for the study's inability to reach significance in showing the influence on publication rate by the number of surveys distributed each year, the number of questions, number of pages, method of delivery, and participant time required for completion of surveys. This information would have facilitated better assessment of the ways to more effectively deliver surveys to CSSANZ membership, whether pertaining to delivery method (paper ver- 
Annals of The Benefits of Colorectal Surgery Surveys in Australia and New Zealand

Coloproctology Auerilius Erastus Ricardo Hamilton, et al.

Table 3. Demographic comparisons of published and unpublished CSSANZ surveys, 2009-2017 ( $\mathrm{n}=38$ )

\begin{tabular}{|c|c|c|c|}
\hline Variable & Published & Unpublished & P-value \\
\hline Total & $20(53)$ & $18(47)$ & \\
\hline Survey questions & $36.2 \pm 18.6(9-75)^{a}$ & $38.1 \pm 30(7-120)^{\mathrm{a}}$ & $0.81^{\mathrm{c}}$ \\
\hline Median number of questions (95\% Cl) & $34^{a}$ & $27^{\mathrm{a}}$ & $0.68^{d}$ \\
\hline$\leq$ Median & $10(27)^{\mathrm{a}}$ & $9(24)^{\mathrm{a}}$ & $0.56^{b}$ \\
\hline >Median & $10(27)^{\mathrm{a}}$ & $8(22)^{\mathrm{a}}$ & \\
\hline Median number of pages $(95 \% \mathrm{Cl})$ & $8^{a}$ & $12^{\mathrm{a}}$ & \\
\hline$\leq$ Median & $17(46)^{\mathrm{a}}$ & $15(41)^{\mathrm{a}}$ & $0.58^{b}$ \\
\hline >Median & $3(8)^{\mathrm{a}}$ & $2(5)^{a}$ & \\
\hline \multicolumn{4}{|l|}{ Time required to complete questionnaire } \\
\hline 5-10 Minutes & $15(11)^{\mathrm{a}}$ & $11(30)^{\mathrm{a}}$ & $0.54, \chi^{2}=1.24, d f=2$ \\
\hline 11-15 Minutes & $2(5)^{a}$ & $4(11)^{\mathrm{a}}$ & \\
\hline 16-30 Minutes & $3(8)^{\mathrm{a}}$ & $2(5)^{a}$ & \\
\hline \multicolumn{4}{|l|}{ Survey outcomes } \\
\hline \multicolumn{4}{|l|}{ Higher degrees achieved } \\
\hline Yes & $9(24)$ & $4(11)$ & $0.13^{b}$ \\
\hline No & $11(29)$ & $14(37)$ & \\
\hline \multicolumn{4}{|l|}{ Survey demographics } \\
\hline \multicolumn{4}{|l|}{ Distribution amount per year } \\
\hline 2-4 Surveys & $10(26)$ & $6(16)$ & $0.24^{b}$ \\
\hline 5-6 Surveys & $10(26)$ & $12(32)$ & \\
\hline \multicolumn{4}{|l|}{ Survey type frequency of use } \\
\hline Referral pathways & $1(3)$ & $0(0)$ & ND \\
\hline Current practices & $18(47)$ & $15(40)$ & \\
\hline Decision-making & $9(24)$ & $8(21)$ & \\
\hline Knowledge and skills assessment & $9(24)$ & $7(18)$ & \\
\hline
\end{tabular}

Values are presented as number (\%) or mean \pm standard deviation (range) unless otherwise indicated.

CSSANZ, Colorectal Surgical Society of Australia and New Zealand; Cl, confidence interval; ND, statistics not done as some surveys had more than one survey type.

aData missing from one survey. ${ }^{b}$ Fisher exact test. ${ }^{\mathrm{C}}$-test. ${ }^{\mathrm{D}}$ Mann-Whitney U-test.

Table 4. Univariate categorical analysis and Cox regression analysis of factors affecting time to publication of surveys

\begin{tabular}{|c|c|c|c|c|c|}
\hline \multirow{2}{*}{ Variable } & \multicolumn{2}{|c|}{ Published, n (\%) } & \multirow{2}{*}{$\begin{array}{c}\text { Univariate P-value } \\
\text { (Fisher exact) }\end{array}$} & \multicolumn{2}{|c|}{ P-value (HR [95\% Cl]) } \\
\hline & Yes & No & & Univariate & Multivariate \\
\hline Survey score & & & 0.021 & 0.036 (2.9 [1.1-8.1]) & $0.033(3.0[1.1-8.4])$ \\
\hline$\geq 37 / 50$ & $15(40)$ & $6(16)$ & & & \\
\hline$<37 / 50$ & $5(13)$ & $12(32)$ & & & \\
\hline Survey method & & & 0.522 & $0.550(0.8[0.3-1.9])$ & $0.478(0.7[0.3-1.8])$ \\
\hline Electronic & $11(29)$ & $12(32)$ & & & \\
\hline Paper & $9(24)$ & $6(16)$ & & & \\
\hline Survey sent & & & 0.022 & $0.883(1.1[0.4-2.9])$ & $0.896(1.1[0.4-2.9])$ \\
\hline April 2009-Feb 2013 & $14(37)$ & $5(13)$ & & & \\
\hline June 2013-Aug 2017 & $6(16)$ & $13(34)$ & & & \\
\hline
\end{tabular}

$\mathrm{HR}$, hazard ratio; $\mathrm{Cl}$, confidence interval. 
Table 5. Comparison of response rate and topic subject matter

\begin{tabular}{|c|c|c|c|c|c|c|c|c|c|}
\hline $\mathrm{RR}$ & $\begin{array}{l}\text { RR by } \\
\text { CSSANZ }\end{array}$ & $\begin{array}{l}\text { CSSANZ } \\
\text { respondents } \\
\text { (surveys sent) }\end{array}$ & $\begin{array}{c}\text { RR } \\
\text { overall }\end{array}$ & $\begin{array}{l}\text { Overall } \\
\text { respondents } \\
\quad \text { (total } \\
\text { surveys sent) }\end{array}$ & $\begin{array}{l}\text { Survey } \\
\text { year }\end{array}$ & $\begin{array}{l}\text { Study } \\
\text { (publication } \\
\text { year) }\end{array}$ & $\begin{array}{l}\text { Survey } \\
\text { topic }^{\mathrm{a}}\end{array}$ & $\begin{array}{l}\text { Survey } \\
\text { type }\end{array}$ & Focus subject matter \\
\hline \multirow[t]{6}{*}{ Low RR } & $7.3 \%$ & $12(165)$ & ND & $1,064(-)$ & 2012 & $\begin{array}{l}\text { Holt et al. [13] } \\
\text { (2017) }\end{array}$ & $\begin{array}{l}\text { IBD diagnosis and } \\
\text { Evaluation }\end{array}$ & $\mathrm{CP}, \mathrm{KSA}$ & $\begin{array}{l}\text { Attitudes of patients and clinicians about the } \\
\text { role of diet and body weight in IBD. }\end{array}$ \\
\hline & $18.2 \%$ & $12(66)$ & $67.3 \%$ & $33(49)$ & 2009 & $\begin{array}{l}\text { Spigelman et al. } \\
\text { [2] (2013) }\end{array}$ & $\begin{array}{l}\text { Preoperative assess- } \\
\text { ment of colorectal } \\
\text { patients }\end{array}$ & $\mathrm{RP}$ & $\begin{array}{l}\text { Referral pathways of patients with newly } \\
\text { diagnosed colorectal cancer sent to } \\
\text { surgeons. }\end{array}$ \\
\hline & $27.66 \%$ & $52(188)$ & $3.4 \%$ & $72(2100)$ & 2017 & $\begin{array}{l}\text { Chittleborough } \\
\text { et al. [21] } \\
(2018)\end{array}$ & Endoscopy & $\mathrm{CP}, \mathrm{KSA}$ & Quality in colonoscopic surveillance. \\
\hline & $36.0 \%$ & $46(128)$ & $49.0 \%$ & 264 (539) & 2010 & $\begin{array}{l}\text { Leong et al. [6] } \\
\text { (2015) }\end{array}$ & $\begin{array}{l}\text { IBD diagnosis and } \\
\text { evaluation }\end{array}$ & $\mathrm{CP}, \mathrm{KSA}$ & $\begin{array}{l}\text { Dysplasia screening and surveillance in IBD: } \\
\text { knowledge and predictors of practice. }\end{array}$ \\
\hline & $42.9 \%$ & 66 (154) & $42.9 \%$ & $66(154)$ & 2011 & $\begin{array}{l}\text { Behrenbruch } \\
\text { et al. [10] } \\
\text { (2015) }\end{array}$ & $\begin{array}{l}\text { Rectal cancer } \\
\text { decision-making }\end{array}$ & CP, DM & $\begin{array}{l}\text { Consensus for treatment (decision-making } \\
\text { and management) of rectal cancer } \\
\text { patients with complete clinical response to } \\
\text { neoadjuvant chemotherapy. }\end{array}$ \\
\hline & $45.6 \%$ & $73\left(160^{\star}\right)$ & ND & $181(-)$ & 2015 & $\begin{array}{l}\text { Chen et al. [18] } \\
\text { (2017) }\end{array}$ & $\begin{array}{l}\text { Colorectal neoplasm: } \\
\text { screening and } \\
\text { surveillance after } \\
\text { polypectomy }\end{array}$ & $\mathrm{CP}, \mathrm{KSA}$ & $\begin{array}{l}\text { Study of clinicians' attitudes towards the } \\
\text { use of aspirin as a risk-reducing } \\
\text { medication specifically in people at high } \\
\text { risk for cancer due to an inherited cancer } \\
\text { syndrome (Lynch syndrome) with no } \\
\text { personal history of colorectal cancer (i.e., } \\
\text { mutation carriers). }\end{array}$ \\
\hline \multirow[t]{9}{*}{ High RR } & $49.5 \%$ & 99 (200) & $50.0 \%$ & $118(236)$ & 2015 & $\begin{array}{l}\text { Jaung et al. [17] } \\
\text { (2016) }\end{array}$ & Diverticular disease & $\mathrm{CP}$ & $\begin{array}{l}\text { Current practices in the management of } \\
\text { acute diverticulitis in Australasia. }\end{array}$ \\
\hline & $49.8 \%$ & $102(205)$ & $49.8 \%$ & $102(205)$ & 2016 & $\begin{array}{r}\text { Siddiqui et al. } \\
\text { [20] (2017) }\end{array}$ & Diverticular disease & $\mathrm{CP}, \mathrm{KSA}$ & $\begin{array}{l}\text { Correlation of current practices in } \\
\text { management of diverticulitis with recent } \\
\text { guidelines. }\end{array}$ \\
\hline & $53.9 \%$ & $82(152)$ & $53.9 \%$ & $82(152)$ & 2010 & $\begin{array}{l}\text { Kahokehr et al. } \\
\text { [5] (2011) }\end{array}$ & $\begin{array}{l}\text { Surgical management } \\
\text { of colon cancer }\end{array}$ & $\mathrm{CP}$ & $\begin{array}{l}\text { Current state and perceived barriers of } \\
\text { perioperative colorectal practice in } \\
\text { Australia and New Zealand. }\end{array}$ \\
\hline & $58.4 \%$ & $111(190)$ & $27.6 \%$ & 216 (782) & 2014 & $\begin{array}{l}\text { Burnett et al. } \\
\text { [16] (2018) }\end{array}$ & Pilonidal disease & CP, DM & Pilonidal sinus disease. \\
\hline & $60.3 \%$ & 114 (189) & $60.3 \%$ & 114 (189) & 2010 & $\begin{array}{l}\text { Warrier et al. [9] } \\
\text { (2013) }\end{array}$ & $\begin{array}{l}\text { Colon cancer: preop- } \\
\text { erative evaluation } \\
\text { and staging }\end{array}$ & CP, DM & $\begin{array}{l}\text { Clinical practice assessment regarding } \\
\text { management of colorectal cancer in } \\
\text { younger patients. }\end{array}$ \\
\hline & $62.1 \%$ & $108(174)$ & $62.1 \%$ & $108(174)$ & 2010 & $\begin{array}{l}\text { Ooi et al. [7] } \\
\text { (2012) }\end{array}$ & $\begin{array}{l}\text { Anal physiology: } \\
\text { continence and } \\
\text { defaecation }\end{array}$ & CP, DM & $\begin{array}{l}\text { The management of rectal cancer by } \\
\text { colorectal surgeons using MRI for locally } \\
\text { advanced disease. }\end{array}$ \\
\hline & $62.4 \%$ & 126 (202) & $62.4 \%$ & $126(202)$ & 2015 & $\begin{array}{l}\text { Zahid et al. [19] } \\
\text { (2017) }\end{array}$ & $\begin{array}{l}\text { Anal physiology: } \\
\text { continence and } \\
\text { defaecation }\end{array}$ & CP, DM & $\begin{array}{l}\text { Surgical decision-making in the manage- } \\
\text { ment of rectal prolapse. }\end{array}$ \\
\hline & $62.7 \%$ & $128(204)$ & $62.7 \%$ & $128(204)$ & 2012 & $\begin{array}{l}\text { Smart et al. [12] } \\
\text { (2013) }\end{array}$ & $\begin{array}{l}\text { Preoperative } \\
\text { ssessment of } \\
\text { colorectal patients }\end{array}$ & $\mathrm{CP}, \mathrm{KSA}$ & $\begin{array}{l}\text { Examining risk profiles for thromboembolic } \\
\text { disease in colorectal cancer patients: } \\
\text { comparison of guidelines and current } \\
\text { practices. }\end{array}$ \\
\hline & $64.2 \%$ & $106(165)$ & $64.2 \%$ & $106(165)$ & 2013 & $\begin{array}{l}\text { Ansari et al. [15] } \\
\text { (2015) }\end{array}$ & $\begin{array}{l}\text { Rectal cancer: } \\
\text { neoadjuvant } \\
\text { therapy }\end{array}$ & $\begin{array}{l}\mathrm{CP}, \mathrm{DM} \text {, } \\
\mathrm{KSA}\end{array}$ & $\begin{array}{l}\text { Decision-making and certainty in the use of } \\
\text { radiotherapy as neoadjuvant treatment in } \\
\text { rectal cancer. }\end{array}$ \\
\hline
\end{tabular}


Table 5. Continued

\begin{tabular}{|c|c|c|c|c|c|c|c|c|c|}
\hline RR & $\begin{array}{l}\text { RR by } \\
\text { CSSANZ }\end{array}$ & $\begin{array}{l}\text { CSSANZ } \\
\text { respondents } \\
\text { (surveys sent) }\end{array}$ & $\begin{array}{c}\mathrm{RR} \\
\text { overall }\end{array}$ & $\begin{array}{l}\text { Overall } \\
\text { respondents } \\
\text { (total } \\
\text { surveys sent) }\end{array}$ & $\begin{array}{c}\text { Survey } \\
\text { year }\end{array}$ & $\begin{array}{c}\text { Study } \\
\text { (publication } \\
\text { year) }\end{array}$ & $\begin{array}{l}\text { Survey } \\
\text { topic }^{\mathrm{a}}\end{array}$ & $\begin{array}{l}\text { Survey } \\
\text { type }\end{array}$ & Focus subject matter \\
\hline & $64.9 \%$ & $96(148)$ & $64.9 \%$ & 96 (148) & 2010 & $\begin{array}{l}\text { Suen et al. [8] } \\
\text { (2015) }\end{array}$ & $\begin{array}{l}\text { Large bowel } \\
\text { obstruction }\end{array}$ & $\mathrm{CP}, \mathrm{DM}$ & $\begin{array}{l}\text { Self-expanding metallic stents for the } \\
\text { management of large bowel obstruction: } \\
\text { surgeon survey and review of barriers to } \\
\text { conducting randomized controlled trials. }\end{array}$ \\
\hline & $68.5 \%$ & $113(165)$ & $68.5 \%$ & $113(165)$ & 2012 & $\begin{array}{l}\text { Al-Mozany et al. } \\
\text { [14] (2017) }\end{array}$ & $\begin{array}{l}\text { Anal physiology: } \\
\text { continence and } \\
\text { defaecation }\end{array}$ & $\mathrm{CP}, \mathrm{KSA}$ & $\begin{array}{l}\text { Barriers to management of obstructed } \\
\text { defecation in Australia and New Zealand. }\end{array}$ \\
\hline & $69.9 \%$ & $102(146)$ & $69.9 \%$ & $102(146)$ & 2009 & $\begin{array}{l}\text { Jorgensen et al. } \\
\text { [3] (2011) }\end{array}$ & $\begin{array}{l}\text { Colorectal cancer: } \\
\text { postoperative } \\
\text { adjuvant therapy }\end{array}$ & $\mathrm{CP}, \mathrm{KSA}$ & $\begin{array}{l}\text { Older patients and adjuvant therapy for } \\
\text { colorectal cancer: surgeon knowledge, } \\
\text { opinions, and practices. }\end{array}$ \\
\hline & $70.4 \%$ & 107 (152) & $70.4 \%$ & 107 (152) & 2011 & $\begin{array}{l}\text { Hong et al. [11] } \\
\quad(2014)\end{array}$ & $\begin{array}{l}\text { Rectal cancer: } \\
\text { neoadjuvant } \\
\text { therapy }\end{array}$ & $\mathrm{CP}, \mathrm{DM}$ & $\begin{array}{l}\text { Decision-making in the use of radiotherapy } \\
\text { for patients with rectal cancer; perception } \\
\text { of hierarchy of variables. }\end{array}$ \\
\hline & $75.3 \%$ & $110(146)$ & $75.3 \%$ & $110(146)$ & 2009 & $\begin{array}{l}\text { MacDermid et al. } \\
\text { [4] (2014) }\end{array}$ & $\begin{array}{l}\text { Anastomotic } \\
\text { complications }\end{array}$ & DM & $\begin{array}{l}\text { Decision-making with defunctioning stomas } \\
\text { and rectal anastomoses. }\end{array}$ \\
\hline
\end{tabular}

RR, response rate; CSSANZ, Colorectal Surgery Society Australia and New Zealand; RP, referral pathways; CP, current practices; DM, decision-making; KSA, knowledge and skills assessment; IBD, inflammatory bowel disease; MRI, magnetic resonance imaging; ND, not defined.

aBased on Table of Contents of ASCRS Textbook of Colon and Rectal Surgery. 3rd ed. 2016 [1].

sus electronic), the use of incentives, and/or specific geographical challenges, with the common aim of increasing participation by colorectal surgeons. Again, we intuitively forecast that RRs may be improved by a trial of a CSSANZ custom-designed mobile phone application, together with a system of continual professional development points awarded to respondents.

The study also does not review the reasons for surgeons' deviation from conventional guidelines. Any deviation from standard practice should be a cause for concern, as it either points to better treatment options or to an inadequacy of the guidelines. Whereas the opinions of the expert masses should not be followed blindly to determine policy, deviations from policy by the masses should prompt a prudent review. Robust discourse should take place among our experienced and knowledgeable membership regarding the best ways to customise guidelines to align with existing regional experiences.

Lastly, our study does not assess how the results of completed surveys have influenced further research or have led to policy implementations or changes in respective healthcare centres. This is a matter for future review by CSSANZ membership, as it should specifically investigate how these surveys may have influenced clinical governance and administration throughout the region.

In conclusion, surveys in colorectal surgery can be very useful and should continue to be considered for use by the CSSANZ. Surveys overall benefit the CSSANZ by providing a valuable and productive research methodology for auditing and reviewing the membership's clinical practices and adherence to national and regional guidelines. Ideally, CSSANZ surveys should address a popular, trendy, or even controversial topic, should specifically or ex- clusively target proctology colleagues (members and affiliates), and should be of high quality according to YSS assessment. To specify dimensions of high quality, optimal surveys are interesting, important, pertinent to topics not surveyed within the last 2 years, require less than 10 minutes to complete, and are easy to return by any means.

\section{CONFLICT OF INTEREST}

No potential conflict of interest relevant to this article was reported.

\section{ACKNOWLEDGMENTS}

We would like to thank the participating surveyors for sharing aspects of their research. We also send special thanks to Liz Neilson and Kerri Buczynkyj of the CSSANZ Secretariat for providing listings and data of past surveys conducted under the auspices of the CSSANZ.

\section{SUPPLEMENTARY MATERIALS}

Supplementary material can be found via https://doi.org/10.3393/ ac.2019.09.17.

Supplementary Table 1. List of general categories in survey topics with frequency of topics surveyed. Supplementary Table 2. List of survey topics used with listed outcomes. Supplementary Table 3. Expanded list of published surveys with participant groups and responses. 


\section{REFERENCES}

1. Steele SR, Hull TL, Read TE, Saclarides TJ, Senagore AJ, Whitlow CB, editors. The ASCRS Textbook of Colon and Rectal Surgery. 3rd ed. Cham (Switzerland): Springer International Publishing; 2016. p. 1292.

2. Spigelman AD, Pascoe SW, Harris MF, Beilby JJ, Crossland LJ, Gett RM, et al. Referral pathways in colorectal cancer: an audit of surgeons's records. Aust Health Rev 2013;37:449-52.

3. Jorgensen ML, Young JM, Solomon MJ. Older patients and adjuvant therapy for colorectal cancer: surgeon knowledge, opinions, and practice. Dis Colon Rectum 2011;54:335-41.

4. MacDermid E, Young CJ, Young J, Solomon M. Decision-making in rectal surgery. Colorectal Dis 2014;16:203-8.

5. Kahokehr A, Robertson P, Sammour T, Soop M, Hill AG. Perioperative care: a survey of New Zealand and Australian colorectal surgeons. Colorectal Dis 2011;13:1308-13.

6. Leong RW, Perry J, Campbell B, Koo J, Turner IB, Corte C, et al. Knowledge and predictors of dysplasia surveillance performance in inflammatory bowel diseases in Australia. Gastrointest Endosc 2015;82:708-14.

7. Ooi K, Frizelle F, Ong E, Faragher I. Current practice in preoperative therapy and surgical management of locally advanced rectal cancer: a bi-national survey. Colorectal Dis 2012;14:814-20.

8. Suen MK, Zahid A, Young JM, Rodwell L, Solomon MJ, Young CJ. How to decide to undertake a randomized, controlled trial of stent or surgery in colorectal obstruction. Surgery 2015;157:1137-41.

9. Warrier SK, Lynch AC, Heriot AG. A bi-national perspective on the management of young patients with colorectal cancer. ANZ J Surg 2013;83:636-40.

10. Behrenbruch C, Ryan J, Lynch C, Wynn G, Heriot A. Complete clinical response to neoadjuvant chemoradiotherapy for rectal cancer: an Australasian perspective. ANZ J Surg 2015;85:103-4.

11. Hong JS, Young CJ, Solomon MJ. Observational study of decision making concerning radiotherapy in rectal cancer. Int J Surg 2014; 12:390-3.

12. Smart P, Burbury K, Lingaratnam S, Lynch AC, Mackay J, Heriot A. Thromboprophylaxis among Australasian colorectal surgeons. ANZ J Surg 2013;83:646-50.

13. Holt DQ, Strauss BJ, Moore GT. Patients with inflammatory bowel disease and their treating clinicians have different views regarding diet. J Hum Nutr Diet 2017;30:66-72.

14. Al-Mozany N, Wright C, O'Grady G, Young CJ, Solomon MJ. Barriers to the management of obstructed defaecation according to colorectal surgeons. Colorectal Dis 2017;19:649-55.

15. Ansari N, Young CJ, Schlub TE, Dhillon HM, Solomon MJ. Understanding surgeon decision making in the use of radiotherapy as neoadjuvant treatment in rectal cancer. Int J Surg 2015;24(Pt
A):1-6.

16. Burnett D, Smith SR, Young CJ. The surgical management of pilonidal disease is uncertain because of high recurrence rates. $\mathrm{Cu}$ reus 2018;10:e2625.

17. Jaung R, Robertson J, Rowbotham D, Bissett I. Current management of acute diverticulitis: a survey of Australasian surgeons. N Z Med J 2016;129:23-9.

18. Chen Y, Peate M, Kaur R, Meiser B, Wong T, Kirk J, et al. Exploring clinicians' attitudes about using aspirin for risk reduction in people with Lynch Syndrome with no personal diagnosis of colorectal cancer. Fam Cancer 2017;16:99-109.

19. Zahid A, Wright CM, Young CJ. Surgical management of rectal prolapse: a cross-sectional perspective. Pelvi Perineologie 2017;36: 17-20.

20. Siddiqui J, Zahid A, Hong J, Young CJ. Colorectal surgeon consensus with diverticulitis clinical practice guidelines. World J Gastrointest Surg 2017;9:224-32.

21. Chittleborough TJ, Luck A, Boussioutas A, Warrier S, Heriot AG. The conundrum of quality in colonoscopy. ANZ J Surg 2018;88: 263-4.

22. Zhu C. 2018 Journal Impact Factor (JCR 2018) [Internet]. ResearchGate; c2018 [cited 2019 Jul 11]. Available from: https://www. researchgate.net/publication/326007449_2019_Journal_Impact_ Factor_SCI_JCR_2019.

23. Pelvi-Perineologie Impact Factor [Internet]. Padova (IT): PelviPerinologie Journal; c2013 [cited 2018 Sep 7]. Available from: https://www.scijournal.org/impact-factor-of-PELVI-PERINEOLOGIE.shtml.

24. ResearchGate. The New Zealand medical journal (New Zeal Med J) 2015 [Internet]. Researchgate; c2015 [cited 2018 Sep 7]. Available from: https://www.researchgate.net/journal/0028-8446_The_ New_Zealand_medical_journal.

25. Khajehnoori M, Stupart D, Watters D. Publication rate of General Surgery abstracts presented at the Royal Australasian College of Surgeons Annual Scientific Congress. ANZ J Surg 2018;88:16-9.

26. Bennett C, Khangura S, Brehaut JC, Graham ID, Moher D, Potter $\mathrm{BK}$, et al. Reporting guidelines for survey research: an analysis of published guidance and reporting practices. PLoS Med 2010;8: e1001069.

27. Edwards PJ, Roberts I, Clarke MJ, Diguiseppi C, Wentz R, Kwan I, et al. Methods to increase response to postal and electronic questionnaires. Cochrane Database Syst Rev 2009;(3):MR000008.

28. Hing CB, Smith TO, Hooper L, Song F, Donell ST. A review of how to conduct a surgical survey using a questionnaire. Knee 2011;18: 209-13.

29. Alderman AK, Salem B. Survey research. Plast Reconstr Surg 2010;126:1381-9. 


\section{Coloproctology Auerilius Erastus Ricardo Hamilton, et al.}

Supplementary Table 1. List of survey topics general categories for CSSANZ surveys 2009-2017 ( $\mathrm{n}=38$ )

\begin{tabular}{ll}
\hline No. (\%) & \\
\hline $6(16)$ & Rectal Cancer Decision-Making \\
\hline $5(13)$ & Pre-operative Assessment of Colorectal Patients \\
\hline $4(11)$ & Anal Physiology: Continence and Defaecation \\
2 (5) & Surgical Management of Colon Cancer \\
2 (5) & Anastomotic Complications \\
2 (5) & IBD Diagnosis and Evaluation \\
2 (5) & Rectal Cancer: Neoadjuvant Therapy \\
2 (5) & Diverticular Disease \\
$1(3)$ & Colorectal Cancer: Post-operative Adjuvant Therapy \\
$1(3)$ & Post-operative Complications \\
$1(3)$ & Trauma of colon, Rectum ad Anus \\
$1(3)$ & Endoscopy \\
$1(3)$ & Large Bowel Obstruction \\
$1(3)$ & Colon Cancer: Preop Evaluation and Staging \\
$1(3)$ & Proctectomy \\
$1(3)$ & Pilonidal Disease \\
$1(3)$ & Approach to Anal Pain \\
$1(3)$ & Colorectal Neoplasm: Screening and surveillance after polypectomy \\
$1(3)$ & Molecular basis of CRC and inherited CRC Syndromes \\
$1(3)$ & Haemorrhoids \\
$1(3)$ & Endoscopic Management of Polyps and Polypectomy \\
\hline
\end{tabular}

CSSANZ, Colorectal Society Australia \& New Zealand.

Categories taken from chapter list of ASCRS Textbook of Colon and Rectal Surgery [1]. 
Supplementary Table 2. List of survey topics as taken from ASCRS Textbook of Colon and Rectal Surgery [1]

\begin{tabular}{|c|c|c|c|c|c|c|}
\hline Study No. & Survey topic & Survey type & No. of Questions & Publication (IF) & Higher degree & IAA \\
\hline 1 & Pre-operative Assessment of Colorectal Patients & $\mathrm{RP}$ & 18 & Yes (1.036) & No & CSSANZ \\
\hline 2 & Colorectal Cancer: Post-operative Adjuvant Therapy & $\mathrm{CP}, \mathrm{KSA}$ & 39 & Yes (3.616) & Yes (PhD) & CSSANZ \\
\hline 3 & Anastomotic Complications & $\mathrm{CP}$ & 7 & No & No & CSSANZ \\
\hline 4 & Anal Physiology: Continence and Defaecation & $\mathrm{CP}$ & 28 & No & No & CSSANZ \\
\hline 5 & Rectal Cancer Decision-Making & $\mathrm{CP}, \mathrm{DM}$ & 29 & No & No & CSSANZ \\
\hline 6 & Anastomotic Complications & DM & 50 & Yes (2.778) & Yes (Masters) & CSSANZ \\
\hline 7 & Surgical Management of Colon Cancer & $\mathrm{CP}$ & 70 & Yes (2.778) & No & CSSANZ \\
\hline 8 & IBD Diagnosis and Evaluation & $\mathrm{CP}, \mathrm{KSA}$ & 41 & Yes (7.204) & No & Other \\
\hline 9 & Rectal Cancer Decision-Making & $\mathrm{CP}, \mathrm{DM}$ & 22 & Yes (2.778) & Yes (Masters) & CSSANZ \\
\hline 10 & Large Bowel Obstruction & $\mathrm{CP}, \mathrm{DM}$ & 59 & Yes (3.574) & Yes (Masters) & CSSANZ \\
\hline 11 & Colon Cancer: Preop Evaluation and Staging & $\mathrm{CP}, \mathrm{DM}$ & 15 & Yes (1.586) & No & CSSANZ \\
\hline 12 & Rectal Cancer Decision-Making & $\mathrm{CP}, \mathrm{DM}$ & 12 & Yes (1.586) & No & CSSANZ \\
\hline 13 & Rectal Cancer: Neoadjuvant Therapy & $\mathrm{CP}, \mathrm{DM}$ & 43 & Yes (2.693) & Yes (Masters) & CSSANZ \\
\hline 14 & Pre-operative Assessment of Colorectal Patients & $\mathrm{CP}, \mathrm{KSA}$ & 27 & Yes (1.586) & No & CSSANZ \\
\hline 15 & IBD Diagnosis and Evaluation & $\mathrm{CP}, \mathrm{KSA}$ & 9 & Yes (2.681) & No & Other \\
\hline 16 & Anal Physiology: Continence and Defaecation & $\mathrm{CP}, \mathrm{KSA}$ & 38 & Yes (2.778) & Yes (Masters) & CSSANZ \\
\hline 17 & Proctectomy & $\mathrm{CP}$ & 24 & No & No & CSSANZ \\
\hline 18 & Rectal Cancer Decision-Making & DM, KSA & & No & No & CSSANZ \\
\hline 19 & Rectal Cancer: Neoadjuvant Therapy & $\mathrm{CP}, \mathrm{DM}, \mathrm{KSA}$ & 45 & Yes (2.693) & Yes (PhD) & CSSANZ \\
\hline 20 & Post-operative Complications & $\mathrm{CP}, \mathrm{KSA}$ & 10 & No & No & CSSANZ \\
\hline 21 & Pre-operative Assessment of Colorectal Patients & $\mathrm{CP}, \mathrm{DM}, \mathrm{KSA}$ & 45 & No & Yes (Masters) & CSSANZ \\
\hline 22 & Pilonidal Disease & $\mathrm{CP}, \mathrm{DM}$ & 21 & Yes (UA) & No & CSSANZ \\
\hline 23 & Approach to Anal Pain & $\mathrm{CP}$ & 70 & No & No & CSSANZ \\
\hline 24 & Diverticular Disease & $\mathrm{CP}$ & 28 & Yes $(0.48)$ & No & CSSANZ \\
\hline 25 & Colorectal Neoplasm: Screening \& surveillance after polypectomy & $\mathrm{CP}, \mathrm{KSA}$ & 75 & Yes (1.943) & No & Other \\
\hline 26 & Anal Physiology: Continence and Defaecation & CP, DM & 53 & Yes $(0.033)$ & Yes (Masters) & CSSANZ \\
\hline 27 & Molecular basis of CRC and inherited CRC Syndromes & $\mathrm{CP}, \mathrm{DM}, \mathrm{KSA}$ & 11 & No & Yes (Masters) & CSSANZ \\
\hline 28 & Endoscopic Management of Polyps \& Polypectomy & $\mathrm{CP}$ & 120 & No & No & CSSANZ \\
\hline 29 & Pre-operative Assessment of Colorectal Patients & $\mathrm{CP}$ & 83 & No & No & CSSANZ \\
\hline 30 & Diverticular Disease & $\mathrm{CP}, \mathrm{KSA}$ & 30 & Yes (UA) & Yes (Masters) & CSSANZ \\
\hline 31 & Surgical Management of Colon Cancer & KSA & 26 & No & Yes (Masters) & CSSANZ \\
\hline 32 & Rectal Cancer Decision-Making & $\mathrm{CP}, \mathrm{DM}$ & 27 & No & No & CSSANZ \\
\hline 33 & Trauma of Colon, Rectum ad Anus & $\mathrm{CP}, \mathrm{DM}$ & 50 & No & Yes (PhD) & CSSANZ \\
\hline 34 & Anal Physiology: Continence and Defaecation & $\mathrm{CP}, \mathrm{DM}$ & 17 & No & No & CSSANZ \\
\hline 35 & Endoscopy & $\mathrm{CP}, \mathrm{KSA}$ & 28 & Yes (1.586) & No & CSSANZ \\
\hline 36 & Rectal Cancer Decision-Making & $\mathrm{CP}, \mathrm{DM}$ & 56 & No & No & CSSANZ \\
\hline 37 & Pre-operative Assessment of Colorectal Patients & KSA & 20 & No & No & CSSANZ \\
\hline 38 & Haemorrhoids & $\mathrm{CP}, \mathrm{KSA}$ & 24 & No & No & CSSANZ \\
\hline
\end{tabular}

RP, referral pathways; CP, current practice; DM, decision-making; KSA, knowledge and skills assessment; CRC, colorectal cancer; IAA, investigator/author affiliation; CSSANZ, Colorectal Society Australia \& New Zealand; IF, impact factor; UA, unavailable. 


\section{Annals of The Benefits of Colorectal Surgery Surveys in Australia and New Zealand}

\section{Coloproctology}

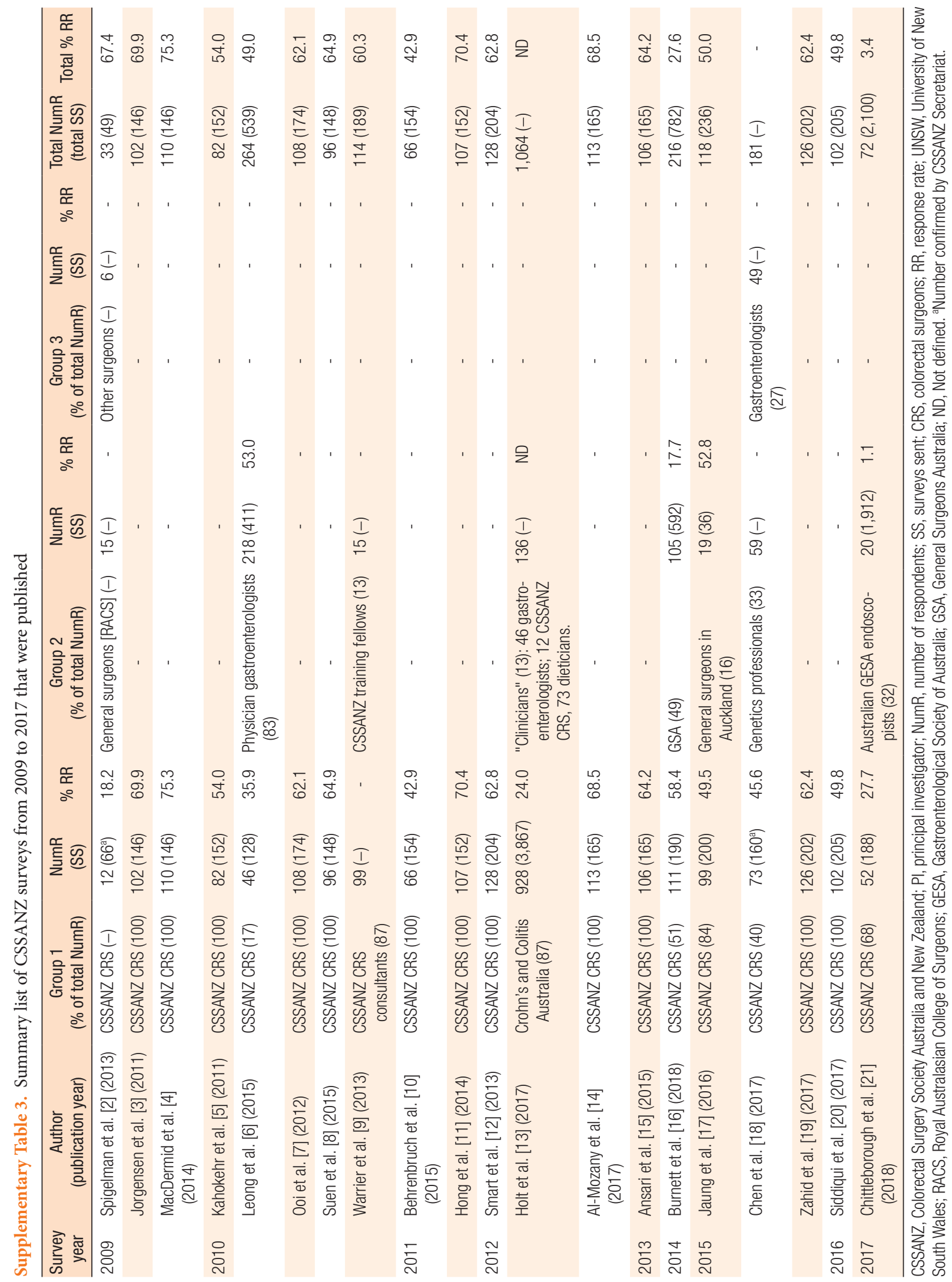

